\title{
Analysis of Ancestral Caddo Ceramic Assemblages from the Gas Line Site (41CE63) and 41CE289, Neches River Basin, Cherokee
}

\section{County, Texas}

Timothy K. Perttula

Heritage Research Center, Stephen F. Austin State University

Follow this and additional works at: https://scholarworks.sfasu.edu/ita

Part of the American Material Culture Commons, Archaeological Anthropology Commons, Environmental Studies Commons, Other American Studies Commons, Other Arts and Humanities Commons, Other History of Art, Architecture, and Archaeology Commons, and the United States History Commons

Tell us how this article helped you.

This Article is brought to you for free and open access by the Center for Regional Heritage Research at SFA ScholarWorks. It has been accepted for inclusion in Index of Texas Archaeology: Open Access Gray Literature from the Lone Star State by an authorized editor of SFA ScholarWorks. For more information, please contact cdsscholarworks@sfasu.edu. 


\section{Analysis of Ancestral Caddo Ceramic Assemblages from the Gas Line Site (41CE63) and 41CE289, Neches River Basin, Cherokee County, Texas}

\section{Creative Commons License}

\section{(c) (1) (8)}

This work is licensed under a Creative Commons Attribution-NonCommercial 4.0 International License 


\title{
Analysis of Ancestral Caddo Ceramic Assemblages from the Gas Line Site (41CE63) and 41CE289, Neches River Basin, Cherokee County, Texas
}

\author{
Timothy K. Perttula
}

\section{Introduction and Setting}

In this article, I discuss the character of the Caddo archaeological assemblages at two sites on Bowles Creek in the Neches River basin that are just north of the important mound center at the George C. Davis site (41CE19): namely the Gas Line site (41CE63) and 41CE289. All three sites are on a broad alluvial terrace of the Neches River and Bowles Creek (Figure 1); the confluence of the two streams is ca. $4.0 \mathrm{~km}$ south of 41CE289. Both sites appear to have been occupied by Caddo peoples after the main occupation at George C. Davis ended at ca. A.D. 1300, and 41CE289 is not far north of a ca. A.D. 15601680 Frankston phase component at the George C. Davis site on the northern part of the alluvial terrace east of the Neches River (Fields and Thurmond 1980).

The Gas Line site was first identified in 1969 along an excavated gas line trench, and a surface collection was obtained from the site by a University of Texas (UT) crew. Site 41CE289 was identified and investigated by Janice Guy and Susan Lisk, both UT graduate students, just prior to a planned expansion of the Indian Mound Nursery in August 1982. At the time, the landform had been plowed, and surface visibility was excellent; Guy and Lisk conducted a general surface collection of the site, which was estimated to cover a ca. $400 \times 150 \mathrm{~m}$ area (ca. 15 acres). At the present time, almost all of 41CE289 is on lands owned and controlled by the Texas Historical Commission at Caddo Mounds State Historic Site (see Figure 1).

Another ancestral Caddo site in the vicinity of 41CE63 and 41CE289 on Bowles Creek is the R. F. Wallace site (41CE20) in the Bowles Creek floodplain near the confluence of Bowles Creek and White Oak Creek. The site is ca. $2.0 \mathrm{~km}$ north of the core area of the George C. Davis site (41CE19) (see Figure 1). The site is a Neche Cluster Historic Caddo Allen phase site with habitation and burial features that was investigated by A. T. Jackson (1932) and a University of Texas crew in June 1932. Human teeth, two glass beads, and ceramic sherds were encountered at ca. $58 \mathrm{~cm}$ bs, and the landowner had recovered two ceramic vessels from a burial feature that washed out of the site in 1930; one of the vessels is a Poynor Engraved bottle (Marceaux 2011:595), and the other was a bowl of unknown type or decoration.

More than 230 ceramic sherds recovered at the site were analyzed in detail by Marceaux (2011:187192, 500-501, 504, 506, 524). The regular occurrence of Patton Engraved sherds, a low plain to decorated sherd ratio (0.40), a considerable proportion of brushed sherds among the decorated sherds, a high brushed to plain sherd ratio (2.07), and a brushed to other wet paste sherd ratio of 5.0, are consistent with a Neche cluster site (Marceaux 2011; Perttula 2016). These metrics are thought to be the material culture correlates of the Neche Caddo, one of the Hasinai Caddo groups that lived on the Neches River in the late $17^{\text {th }}$ and early $18^{\text {th }}$ century just north of the crossing of El Camino Real de los Tejas and the Neches River.

\section{Gas Line Site (41CE63)}

The archaeological material culture remains collected at the Gas Line site in 1969 indicate that it was occupied during both prehistoric and historic times. The first apparent use of the site was during the 


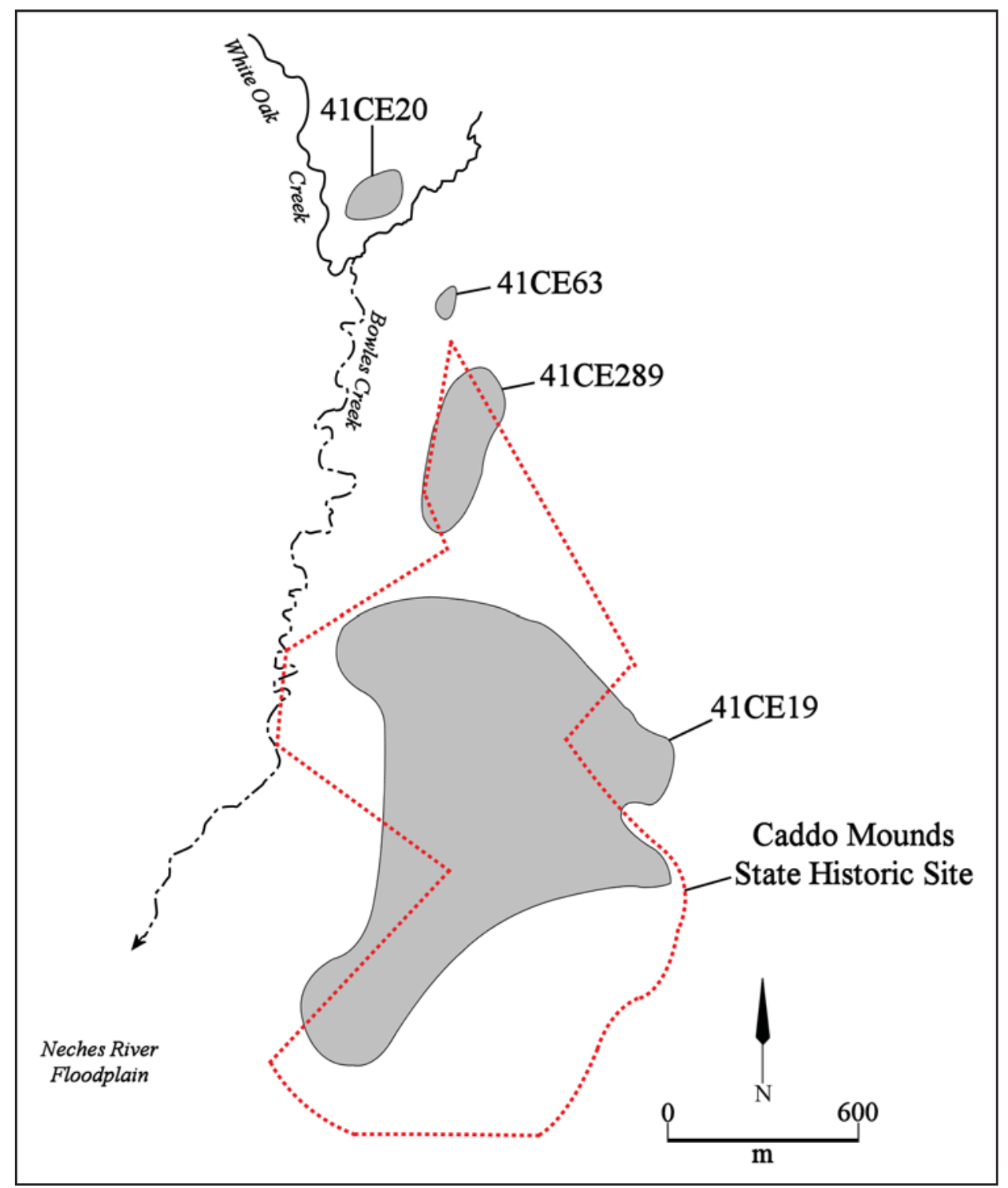

Figure 1. The location of the Gas Line site (41CE63), 41CE289, the R. F. Wallace site (41CE20), and the George C. Davis site (41CE19), as well as the limits of Caddo Mounds State Historic Site (in red), Weches 7.5' USGS topographic quadrangle.

Woodland period (ca. 2500-1150 years B.P.), based on the recovery of a large contracting stem Gary dart point made from a light gray chert. Other artifacts probably associated with this component include 19 pieces of lithic debris.

Sometime after ca. A.D. 1250/1300, when brushed utility ware vessels began to be commonly made in the Neches River basin in East Texas, the Gas Line site was occupied by an ancestral Caddo group. This occupation is marked by 16 base or body sherds, tempered with either grog (93.8 percent) or burned bone (6.2 percent). Three of the body sherds (either grog, $n=2$, or bone-tempered, $n=1$ ) have parallel brushing marks, and are from Bullard Brushed jars. 
The last occupation was by Anglo-American farmers sometime between ca. 1830-1880. The historic artifacts in this component include two pieces of brown bottle glass, one sherd of aqua bottle glass, three plain whiteware rim and body sherds, one mid-late $19^{\text {th }}$ century yellowware rim sherd, a post1830s interior/exterior salt-glazed stoneware body sherd, and a post-1850s brown-glazed Rockingham stoneware body-base sherd.

\section{CE289}

There appear to be substantial Late Archaic to Woodland period archaeological deposits at 41CE289, as indicated by Morrill $(n=1)$, Godley $(n=2)$, and Gary $(n=1)$ dart points in the assemblage, along with three dart point mid-sections. The dart points are made from chert ( 71 percent, including light gray and gray cherts) and petrified wood (29 percent). Other lithic artifacts probably associated with this use of the site includes a petrified wood early stage biface fragment, a hematite gouge, six unilateral expedient flake tools (83 percent chert and 17 percent petrified wood), one bilateral expedient flake tool on a light gray chert blade, 10 cores (petrified wood, $n=6$, chert, $n=2$, and quartzite, $n=2$ ), and 258 pieces of lithic debris. About 84 percent of the lithic debris are of chert raw materials, followed by petrified wood (9.3 percent), and quartzite (6.6 percent). About 14 percent of the lithic debris have cortical remnants, primarily detached from stream-rolled pebbles in Neches River gravel beds.

Further evidence of Woodland period use of 41CE289 are two sandy paste body sherds from Goose Creek Plain, var. unspecified vessels (Story 1990). These vessels were made by Mossy Grove groups that lived in the Neches-Angelina and Sabine River basins in East Texas.

The 363 ceramic vessel sherds in the 41CE289 assemblage are from plain ware, utility ware, and fine ware vessels. About 82 percent of the sherds are from grog-tempered vessels, and the remaining 18 percent are from bone-tempered vessels (Table 1). The highest proportion of bone-tempered vessels are in the utility wares ( 22 percent), and only 9.1 percent of the fine ware sherds are from bone-tempered vessels.

Table 1. Ceramic wares at 41 CE289.

\begin{tabular}{lccc}
\hline Ware & Grog-tempered & Bone-tempered & N \\
\hline Plain & 178 & 33 & 211 \\
Utility & 110 & 31 & 141 \\
Fine & 10 & 1 & 11 \\
\hline Totals & 298 & 65 & 363 \\
\hline
\end{tabular}

The plain to decorated sherd ratio in the 41CE289 sherd assemblage is 1.38 . More than 92 percent of the decorated sherds in the assemblage $(n=152)$ are from utility ware vessels, and fine ware vessel sherds comprise only 7.2 percent of the surface collection sample. All nine of the decorated rim sherds in the assemblage are from utility ware vessels that have brushed, brushed-punctated, incised, and incisedpunctated decorative elements on the vessel rim (Table 2). 
Table 2. Decorative methods and elements in the 41CE289 Caddo ceramic assemblage.

$\begin{aligned} & \text { Decorative methods and } \\ & \text { elements }\end{aligned}$
Rim

\section{Utility Ware}

Appliqued

appliqued node

$\begin{array}{lll}- & 1 & 1\end{array}$

Brushed

horizontal brushed

overlapping brushed

parallel brushed

$\begin{array}{lll}3 & - & 3 \\ - & 1 & 1 \\ - & 93 & 93 \\ - & 2 & 2 \\ & & \\ 3 & - & 3 \\ - & 2 & 2\end{array}$

Brushed-Incised

parallel brushed-incised marks and lines

Brushed-Punctated

horizontal brushed rim and tool punctated row below the lip

parallel brushed with tool punctated row through the brushing

\section{Incised}

curvilinear incised line

horizontal incised line

parallel incised lines

straight incised line

\section{Incised-Punctated}

curvilinear incised line and zone of circular punctates

diagonal incised zones filled with tool punctations

horizontal and diagonal incised lines and cane punctated

rows above diagonal incised line

incised panel filled with fingernail punctations

straight incised line-zones of tool punctations

\section{Punctated}

tool punctated rows

\section{Fine Ware}

\section{Engraved}

circular engraved el. and connecting straight lines

closely-spaced curvilinear engraved lines

curvilinear engraved line

hatched engraved zone

opposed engraved lines

parallel engraved lines

straight engraved line

triangular excised zone

$\begin{array}{lll}- & 1 & 1 \\ 1 & 1 & 2 \\ - & 5 & 5 \\ - & 3 & 3\end{array}$

Totals

\begin{tabular}{lll}
- & 1 & 1 \\
- & 1 & 1 \\
- & 1 & 1 \\
- & 2 & 2 \\
- & 2 & 2 \\
- & 2 & 2 \\
- & 1 & 1 \\
- & 1 & 1 \\
\hline 9 & 143 & 152 \\
\hline
\end{tabular}


About 64 percent of the decorated sherds are from utility ware rim and body sherds with brushing marks. Another 4.6 percent have either brushed-incised or brushed-punctated decorative elements (see Table 2). These brushed sherds are from Bullard Brushed vessels. Other utility wares have tool punctations (13.2 percent), geometric and curvilinear incised elements (7.2 percent), diagonal zoned incised-punctated (3.3 percent) (Figure 2a-b), and appliqued (0.7 percent).

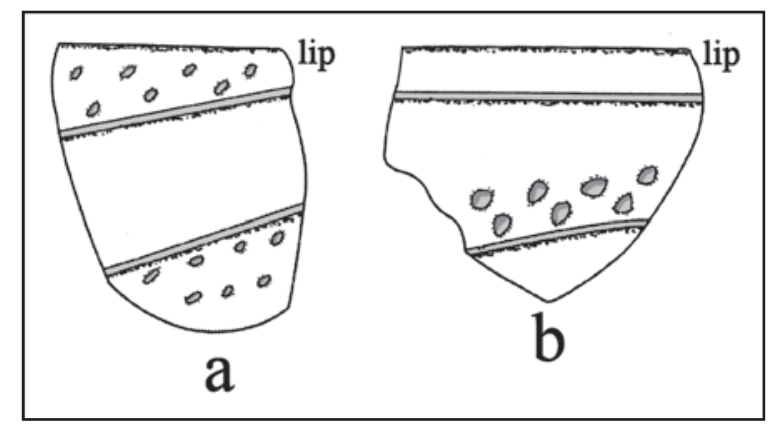

Figure 2. Selected incised-punctated decorative elements on rim sherds in the $41 \mathrm{CE} 289$ ceramic sherd assemblage.

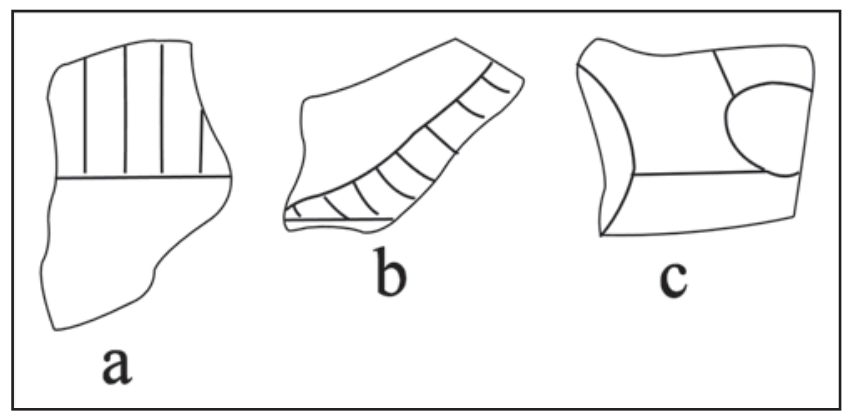

Figure 3. Selected engraved decorative elements on body sherds in the 41CE289 ceramic sherd assemblage.

The majority of the engraved sherds have simple geometric elements, including sherds, one from a bottle, with sets of opposed engraved lines (Figure 3a). Another sherd has a triangular excised element, and two sherds have hatched zones (Figure 3b). The most distinctive of the 41CE289 engraved sherds is a body sherd with circular engraved elements and connecting horizontal and diagonal lines (Figure 3c). None of the fine ware sherds in the assemblage can be identified to a specific defined East Texas Caddo ceramic type.

The one chipped stone tool that can be associated with the ancestral Caddo occupation of 41CE289 is a contracting stem arrow point preform-perhaps a preform for a Perdiz arrow point - made from a very dark gray chert. The preform has a contracting but rounded stem and base, with small barbs either pointing downward or straight outward.

\section{Summary and Conclusions}

Archaeological investigations in 1982 in a large plowed field along an alluvial terrace of the Neches River, not far north of the George C. Davis site (41CE19), identified both Late Archaic, Woodland, and ancestral Caddo occupations in a general surface collection covering a ca. $400 \times 150 \mathrm{~m}$ area of the alluvial terrace. The surface-collected artifacts were documented as 41CE289. 
The ancestral Caddo component at 41CE289 is principally known through the collection of more than 360 ceramic vessel sherds, including 152 rim and body sherds from decorated vessels. The assemblage is notable for the considerable proportion of brushed sherds (68 percent) in the decorated sherd assemblage, from Bullard Brushed vessels, which suggests a post-A.D. 1250-1300 Caddo occupation, one that took place after the core area of the George C. Davis site was no longer permanently occupied by Caddo peoples.

The absence of post-A.D. 1400 Poynor Engraved or post-A.D. 1680 Patton Engraved fine ware sherds in the 41CE289 assemblage, along with selected ceramic metrics (Table 3), also suggests the site was settled by Caddo peoples prior to ca. A.D. 1400, likely between ca. A.D. 1300-1400. However, the fine ware sherd assemblage is small ( $\mathrm{n}=11$ sherds), and a larger collection of decorated sherds with more diagnostic engraved wares from 41CE289 may change this temporal assessment.

Table 3. Ceramic sherd assemblage comparisons of Neche cluster sites, including 41CE289 and 41CE20.

\begin{tabular}{|c|c|c|c|c|c|}
\hline Site & \% Grog & $\%$ Bone & $\mathrm{P} / \mathrm{DR}$ & $\mathrm{B} / \mathrm{Pl}$ & $\mathrm{B} / \mathrm{OWP} * *$ \\
\hline \multicolumn{6}{|c|}{ Allen phase (ca. post-A.D. 1680} \\
\hline \multicolumn{6}{|l|}{ Group I } \\
\hline 41CE293 & 98.1 & 5.6 & 0.12 & 7.50 & 5.70 \\
\hline 41CE43 & 96.1 & 3.9 & 0.17 & 4.91 & 6.08 \\
\hline 41CE477 & 95.8 & 4.2 & 0.18 & 4.73 & 13.0 \\
\hline 41CE474 & 97.1 & 2.9 & 0.30 & 3.08 & 9.25 \\
\hline \multicolumn{6}{|l|}{ Group II } \\
\hline $41 \mathrm{CE} 48$ & 84.2 & 27.7 & 0.31 & 2.43 & 5.48 \\
\hline 41CE475 & 91.2 & 9.2 & 0.34 & 2.55 & 11.3 \\
\hline 41CE20 & 85.7 & 14.3 & 0.40 & 2.07 & 5.0 \\
\hline 41CE476 & 91.2 & 9.2 & 0.45 & 1.77 & 7.0 \\
\hline 41CE291 & 97.4 & 2.6 & 0.30 & 1.94 & 1.84 \\
\hline \multicolumn{6}{|c|}{$\begin{array}{l}\text { Late Frankston phase (ca. A.D. 1560-1680) } \\
\text { Group III }\end{array}$} \\
\hline $\begin{array}{l}41 \mathrm{CE} 19, \\
\text { Northern } \\
\text { part of site }\end{array}$ & $\mathrm{N} / \mathrm{A}$ & N/A & 0.82 & 0.78 & 1.90 \\
\hline \multicolumn{6}{|c|}{$\begin{array}{l}\text { Possible Middle Caddo occupation, ca. A.D. 1300-1400 } \\
\text { Group IV }\end{array}$} \\
\hline 41CE289 & 82.1 & 17.9 & 1.38 & 0.49 & 2.38 \\
\hline
\end{tabular}

$\mathrm{P} / \mathrm{DR}=$ plain to decorated sherd ratio; $\mathrm{B} / \mathrm{Pl}=$ brushed/plain sherd ratio; $\mathrm{B} / \mathrm{OWP}=$ brushed/other wet paste sherd ratio

Future archaeological investigations should be conducted at 41CE289, including surface collecting and intensive shovel testing. The purpose of this work would be to determine the overall integrity and contents of the site's archaeological deposits, and hopefully recover charred organic remains in buried contexts that will be suitable for AMS radiocarbon dating to establish the absolute age of the ancestral Caddo occupation at 41CE289. 


\section{Acknowledgments}

Thanks to the staff at the Texas Archeological Research Laboratory, The University of Texas at Austin, especially Lauren Bussiere, for their help in accessing the collections from the two sites. Lance Trask prepared the figures in this article.

\section{References Cited}

Fields, R. and J. P. Thurmond

1980 The George C. Davis Site, Cherokee County, Texas: Spring 1980 Archeological Investigations. Reports of Investigations No. 8. Prewitt and Associates, Inc., Austin.

Jackson, A. T.

1932 Notes on Work Done, Cherokee County, Texas, R. F. Wallace Farm, June 9, 1932 to June 11, 1932. MS on file, Texas Archeological Research Laboratory, The University of Texas at Austin.

Marceaux, P. S.

2011 The Archaeology and Ethnohistory of the Hasinai Caddo: Material Culture and the Course of European Contact. Ph.D. dissertation, Department of Anthropology, The University of Texas at Austin.

Perttula, T. K.

2016 Utility Ware Ceramic Metrics and Hasinai Caddo Archaeology in East Texas. Journal of Northeast Texas Archaeology 70:61-68.

Story, D. A.

1990 Cultural History of the Native Americans. In The Archeology and Bioarcheology of the Gulf Coastal Plain, by D. A. Story, J. A Guy, B. A. Burnett, M. D. Freeman, J. C. Rose, D. G. Steele, B. W. Olive, and K. J. Reinhard, pp. 163-366. Research Series No. 38. 2 Vols. Arkansas Archeological Survey, Fayetteville. 